\title{
Effects of macrobenthic burrows on infaunal communities in tropical tidal flats
}

\author{
Sabine Dittmann* \\ Zentrum für Marine Tropenökologie, Fahrenheitstr. 1, D-28359 Bremen, Germany
}

\begin{abstract}
The effects of burrows on the infaunal community in a tropical tidal flat were studied on the northeast coast of Australia. A comparative survey of infauna in burrows versus adjacent sediment was carried out for the burrows of 3 crustaceans (Scopimera inflata, Uca spp., Callianassa australlensis) and a brachiopod (Lingula anatina). More ( 1.5 to $2.5 \times$ ) infauna occurred within burrows than in adjacent sediments. Densities of meiobenthic nematodes, copepods and Platyhelminthes were significantly higher within the burrows of $U c a s p p ., C$. australiensis and L. anatina. In the latter 2 cases multivariate analyses showed distinct communities in burrows and adjacent sediment, although this was not consistent over time for the brachiopod burrows. No differences in community composition were detected in the cases of Uca spp. and S. inflata. In a field experiment, C. australiensis was excluded from 7 sites, and infaunal abundances and species compositions were followed for 1 yr and compared with control sites. From the very beginning, melofaunal densities were significantly lower in the exclusion sites, mainly due to reduced densities of nematodes and copepods. The effect of the shrimp exclusion on macrofauna was less pronounced, but after 1 yr total numbers of macrofauna were significantly lower in the exclusions, due to the distribution of amphipods. The results showed that promotive interactions play an important role in structuring tropical tidal flat communities.
\end{abstract}

KEY WORDS: Benthos communities - Burrows - Callianassa Field experiments Meiofauna Promotuve interaction. Tropical tidal flat

\section{INTRODUCTION}

Biogenic structures of benthic organisms have been shown to have contrasting effects on infauna. On the one hand, macrobenthic burrows may enhance the presence of smaller infauna by providing suitable microhabitats in sediment depth, where they would otherwise not be able to live (Bell et al. 1978, Reise 1981, 1987, Meyers et al. 1987, Schaffner 1990). This process, termed accommodation, is one of the major promotive interactions structuring benthic communities (Reise 1985). Macrobenthos tubes can provide refuge from predation or facilitate larval settlement (Woodin 1978, Bell \& Woodin 1984, Bell 1985). On the other hand, infaunal abundances can be reduced in assemblages of burrowing organisms, an effect often attributed to bioturbation (Brenchley 1981, Murphy

\footnotetext{
-Present E-mail: dittmann@terramare.fh_wilhelmshaven.de
}

1985, Branch \& Pringle 1987) The effects of biogenic structures have also been discussed in the light of various functional-mode hypotheses (Rhoads \& Young 1970, Woodin 1976, Murphy 1985, Posey 1986, 1987, Dittmann 1990).

For tropical tidal flats, ambiguous accounts exist on the relevance of biotic interactions for structuring benthic communities. Sanders (1968) took tropical shallow-water marine regions as an example of biologically accommodated communities, whereas Moore (1972) and Alongi $(1987,1990)$ argued that the high physical stress in tropical marine environments outweighs biological processes in regulating intertidal populations. The existence of commensals associated with intertidal macrobenthos has been reported from the tropics (Kenway 1981, Morton \& Morton 1983), yet no quantitative study has been carried out to assess the relevance of biogenic structures for the benthic community in tropical tidal flats. 
The aim of this investigation was to study whether burrows of macrobenthic organisms affect densities and/or species composition of smaller infauna in a tropical tidal flat. Decapod crustaceans are among the dominant macrobenthos dwellers in tropical tidal flats (Rrise 1985, 1991, Alongi 1990, Dittmann 1995) and several burrowing crustaceans were chosen for this study the sand bubbler crab Scopimera inflata Milne Edwards, 1873, fiddler crabs of the genus Uca. and the shrimp Callianassa australiensis (Dana). In addition, dense patches of brachiopods (Lingula anatina Lamarck) were chosen as a further representative of tropical macrobenthos. Densities of $L$. anatina on the Queensland coast, Australia, exceed 100 ind. $\mathrm{m}^{-2}$ (Kenchington \& Hammond 1978). The hypothesis tested was that burrows increase infaunal abundances and species numbers. To test this hypothesis, both a comparative study on infauna in burrows versus adjacent sediment and an experiment in which C. australiensis was excluded were carried out.

The burrows of Callianassa australiensis extend over 1. $\mathrm{m}$ in depth and resin casts showed that the U-shaped top part of the burrow merges at about $20 \mathrm{~cm}$ depth to a single vertical tunnel that forms a branched network of tunnels with horizontal chambers at over $50 \mathrm{~cm}$ depth (Kenway 1981). On the surface, one of the openings has a small cone-shaped mound $<1 \mathrm{~cm}$ in elevation and is thus negligible in comparison to mounds of other thalassinidean shrimps, which can reach elevations up to $1 \mathrm{~m}$ above the sediment surface (Griffis \& Suchanek 1991); the other opening has no mound. This burrow type represents a combination of burrow types 4 and 5 as classified by Griffis \& Suchanek (1991). These authors specify shrimps of these types as filter/ suspension feeders, whereas Kenway (1981) describes the feeding process of $C$. australiensis as sand-sifting and showed that they feed while burrowing. This does not imply that material suspended while digging cannot be trapped on plumose setae on the antennae.

In several temperate and subtropical locations, studies have examined the effect of thalassinidean burrows on sediment reworking (Suchanek 1983, Suchanek \& Colin 1986), microgeochemistry and microbial activities (Aller et al. 1983, Dobbs \& Guckert 1988) and infaunal abundances (Peterson 1977, Alongi 1986, Posey 1986, Branch \& Pringle 1987, Posey et al. 1991). So far the studies have shown that the shrimp burrows provide a rich microbial and microalgal food source, but bioturbating activities exclude certain infauna species or functional modes.

The results of the present investigation are discussed in relation to burrow type, effects of burrows reported from tidal flats elsewhere and previous accounts of community composition in beds of thalassinidean shrimps.

\section{MATERIALS AND METHODS}

The investigation was carried out between 1988 and 1991 on the tropical northeast coast of Australia. Here, tidal flats extend along estuaries and bays and often occur on the seaward side of mangrove forests. Tidal ranges are 2 to $2.5 \mathrm{~m}$ on average (Dittmann 1995). Assemblages of the brachiopod Lingula anatina and burrows of Scopimera inflata were studied in Hinchinbrook Channel; all other studies were carried out in the Haughton Estuary (Fig. 1). The sediment at the studied sites consisted of fine sand (median grain size $0.19 \pm 0.05 \mathrm{~mm}$ sorting coefficient $1.59 \pm 0.34$ ) with a medium to low organic matter content [mud bank with fiddler crabs: $2.97 \%$ dry wt (DW); muddy sand flats: $1.38 \% \mathrm{DW}]$.

For a comparative survey, sediment samples were taken from burrows of ocypodid crabs (Scopimera inflata and Uca spp.), Lingula anatina and Callianassa australiensis, and compared with ambient sediment samples. These macrobenthic species occurred in different communities (Dittmann 1995, unpubl.). In each case, 5 or 6 random samples were taken from burrows and the same number of replicates was taken from the sediment surface adjacent (at least $1 \mathrm{~cm}$ distance) to burrows, all within areas of $10 \mathrm{~m}^{2}$ The corers used for each burrow type had a cross section just wide enough to include 2 to $5 \mathrm{~mm}$ of the sediment lining the respective burrow. Samples were taken to a depth of $5 \mathrm{~cm}$, and a lower horizon ( 5 to $10 \mathrm{~cm}$ depth) was additionally sampled in burrows of $L$. anatina to consider the effect of burrows on the vertical distribution of meiofauna in the sediment.

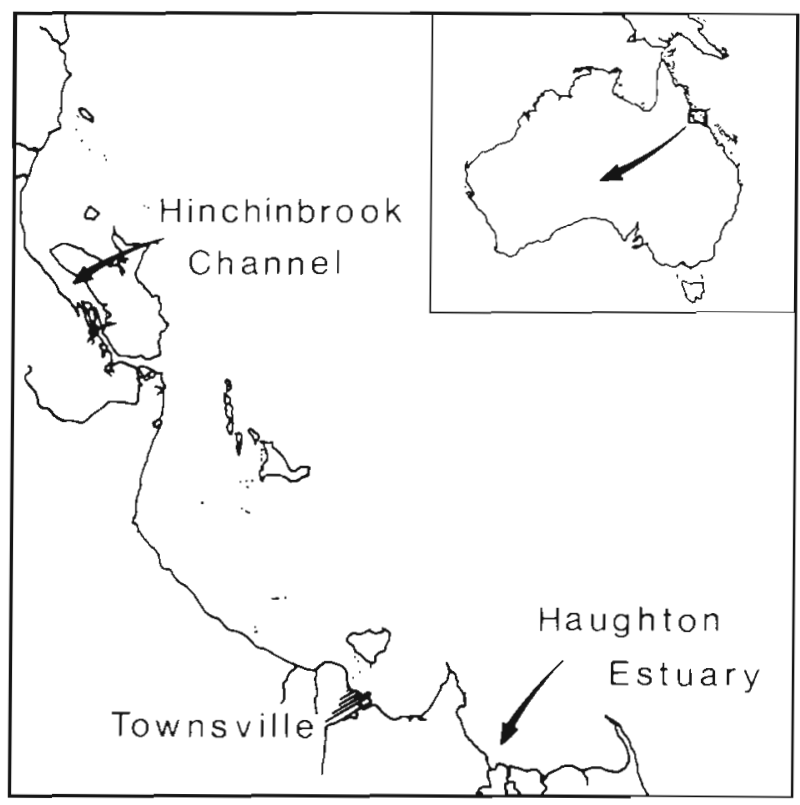

Fig. 1. Northeast coast of Australia, showing the location of the study areas 
Meiofauna was extracted by repeated shaking and decantation through a set of sieves of 125,80 and $40 \mu \mathrm{m}$ mesh size. The samples were diluted with seawater, following narcotization with $\mathrm{MgCl}_{2}$. All sediment samples were treated alive.

To study the effect of burrows of Callianassa australiensis on community composition, an exclusion experiment was designed following the approach used by Reise (1983) to exclude Arenicola marina from a temperate tidal flat. C. australiensis is the structuring organism in the muddy sandflat of the studied intertidal area (Dittmann 1995), and as ambient communities differed in their sedimentological parameters, the experiment had to be carried out within the community by creating sites without shrimps. This was achieved as follows. At 14 sites of $75 \times 75 \mathrm{~cm}$ area each, the sediment was carefully lifted off to a depth of $5 \mathrm{~cm}$ with a shovel and placed on a plastic panel. Horizontal layers of flyscreen (mesh size $1.5 \mathrm{~mm}$ ) were implanted into the sediment at 7 of the sites before the sediment was replaced in its original position. At the other 7 sites, the sediment was replaced without implanting screens and thus served as controls. To aid in locating the sites, sticks were put into the sediment along the site margins. The arrangement of the sites was chosen haphazardly, making sure that the treatments were interspersed. Distances between sites were at least $2 \mathrm{~m}$. The flyscreen was effective in inhibiting the mobility of the shrimps, which could no longer reach the surface to irrigate their burrows and so moved away (Fig. 2).

The experiment was set up on 11 July 1989 and sampled after 1, 6, 11, 18 and $53 \mathrm{wk}$. The repetitive sampling of the sites caused negligible disturbance The sediment volume removed per site on each sampling occasion amounted to $280 \mathrm{~cm}^{3}$, equivalent to $1 \%$
Fig. 2. Experimental treatments $1 \mathrm{wk}$ after their establishment: (a) control site, (b) exclusion of Callianassa australiensis. See 'Materials and methods' for details. Each site was $0.56 \mathrm{~m}^{2}$ in area

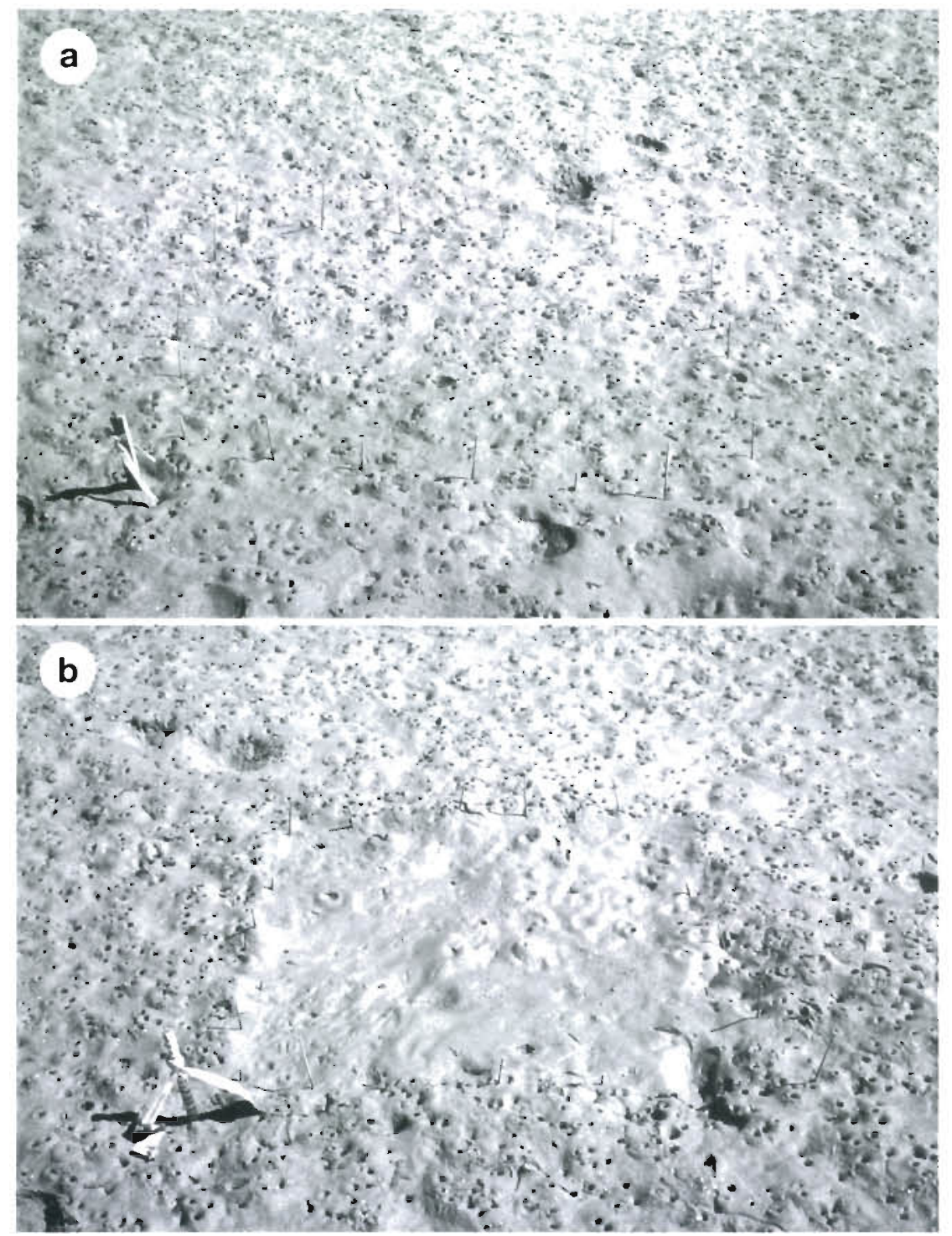


of the sediment volume of each site. Meiofaunal samples were taken with a corer of $3.69 \mathrm{~cm}^{2}$ surface area. Three samples were taken from each site and combined in the field to 1 sample per site. On the first 3 sampling dates, the samples were divided into horizons of $0-1$ and $1-5 \mathrm{~cm}$ sediment depth. The samples were processed as described above. For macrofauna, samples were taken with a $15 \mathrm{~cm}^{2}$ corer to a sediment depth of $5 \mathrm{~cm}$. They were sieved through $0.25 \mathrm{~mm}$ mesh. Corer and sieve size were adjusted to the small individual sizes of macrobenthos in the study area (Dittmann 1995). Again, 3 samples from each site were combined to form 1 sample per site. This combination of replicates of experimental sites is 'sacrificial pseudoreplication' sensu Hurlbert (1984). An analysis of within-site variability was omitted, as a maximization of treatment sites was considered to be most important and samples had to be processed quickly.

In November 1989, one each of the exclusion and control sites was lost due to disturbance by stingrays. In early 1990 heavy monsoonal activity caused flooding of the estuary. In samples taken right after the floods in April 1990 almost no animals were encountered at all.

Throughout the investigation, specimens were recorded to the lowest possible taxonomic level, but only Polychaeta and Platyhelminthes could be treated at the species level.

Faunal densities were compared for significant differences between burrows and adjacent sediment and between experimental treatments, using the nonparametric Mann-Whitney $U$-test. In some cases, species similarities were compared using the index of similarity (QS) (Sørensen 1948). Community compositions were assessed using the PRIMER software pack- age from Plymouth Marine Laboratory (UK). Multivariate analyses were carried out on untransformed data using the Bray-Curtis index and the group average linkage method for cluster analysis and non-metric multidimensional scaling (MDS) ordination. Sites (burrows vs adjacent sediment) or treatments were discriminated by 2-way nested ANOSIM (Clarke 1993), testing the null hypothesis that no differences existed between sites or treatments.

\section{RESULTS}

\section{Comparative survey of burrows and adjacent sediment}

In the studied tidal flats, nematodes accounted on average for $75 \%$ of the permanent meiofauna, followed by copepods at $15 \%$, Platyhelminthes at $5 \%$ and ostracods at $2 \%$. Further taxa encountered frequently but in low numbers were Halacarida, Kinorhynchia, Tardigrada, Gastrotricha and Gnathostomulida.

Results of the comparison of infauna inside and outside of burrows varied with the burrow host and the infauna taxon considered (Fig. 3). Significant differences in abundance between burrows and adjacent sediment were usually due to higher densities in the burrows.

Scopimera inflata. Densities of infauna in the burrows of sand bubbler crabs were not significantly different from adjacent sediment (Table 1). Only Platyhelminthes were significantly more abundant in the burrows, due to a higher abundance of predatory platyhelminth species. A total of 11 platyhelminth species was recorded in the burrows compared to 6 in ambient sediment (QS $=0.59$ ). Gastrotricha were only located in the burrows. The meiofauna community in
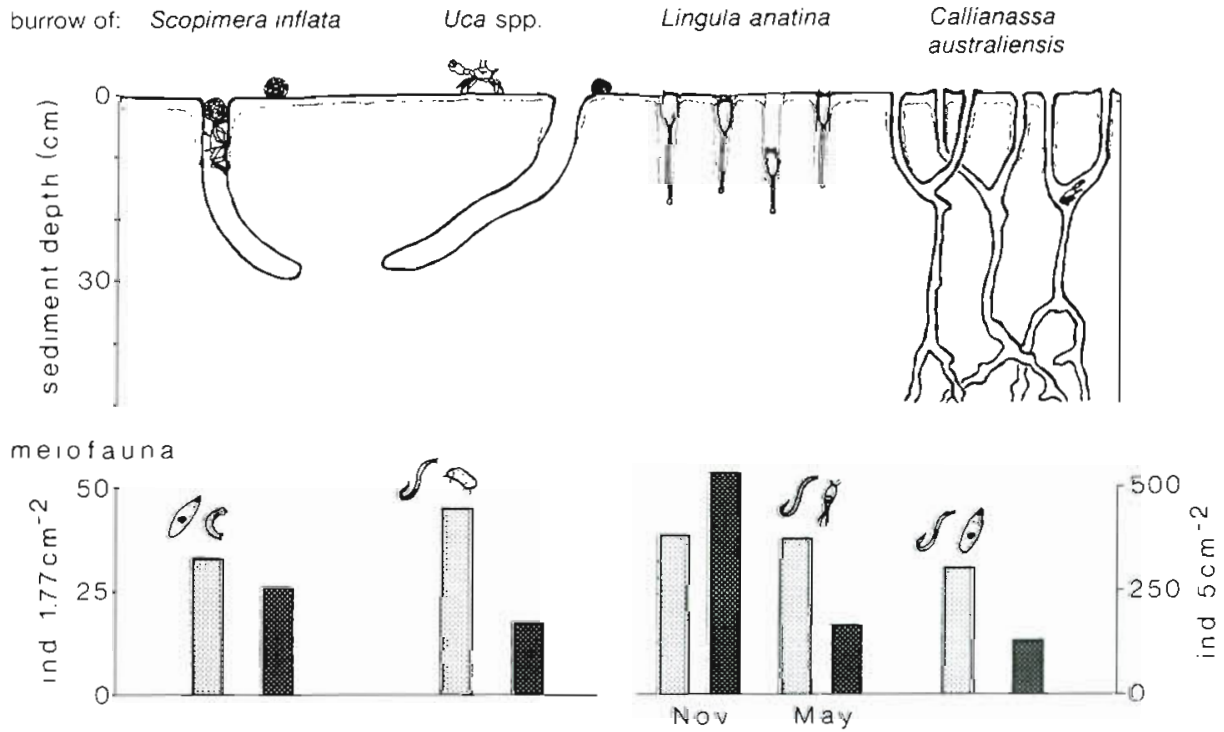

Fig. 3. Schematic drawing of the studied burrow types and the observed effects on meiofauna. Both Scopimera inflata and Uca spp. are ocypodid crabs which excavate their burrows. The animals are not drawn to scale. Meiofaunal abundances are given as median values; columns with light shading refer to burrows, those with dark shading to adjacent sediment. Meiofauna taxa that were significantly more abundant in the burrows are illustrated. See 'Results' for further details 
Table 1. Infaunal densities (individuals $1.77 \mathrm{~cm}^{-2}, 0-5 \mathrm{~cm}$ depth, $\mathrm{n}=6$ each) in burrows of the sand bubbler crab Scopimera inflata (Hinchinbrook Channel, 19 November 1988) and of fiddler crabs Uca spp. (Haughton Estuary, 23 August 1991), and in sediment adjacent to their burrows. Values are medians with ranges; $n s=$ not significant $(p>0.05)$

\begin{tabular}{|lccc|}
\hline & Burrows & $\begin{array}{c}\text { Adjacent } \\
\text { sediment }\end{array}$ & $\begin{array}{c}\text { Mann-Whitney } \\
\text { U-test }\end{array}$ \\
\hline $\begin{array}{l}\text { Scopimera inflata } \\
\text { Permanent meiofauna }\end{array}$ & & & \\
Total & $33(13-67)$ & $26(11-35)$ & $\mathrm{ns}$ \\
Nematoda & $13(8-39)$ & $5(7-13)$ & $\mathrm{ns}$ \\
Copepoda & $9(4-25)$ & $10.5(1-20)$ & $\mathrm{ns}$ \\
Platyhelminthes & $3(1-5)$ & $1(0-5)$ & $\mathrm{p}<0.05$ \\
$\quad$ Predators & $2.5(1-5)$ & 0 & $\mathrm{p}<0.05$ \\
Gastrotricha & $0.5(0-1)$ & 0 & $\mathrm{p}<0.05$ \\
Polychaete larvae & $2(0-11)$ & $0.5(0-2)$ & $\mathrm{ns}$ \\
Uca spp. & & & $\mathrm{p}<0.05$ \\
Permanent meiofauna \\
Total & $45(9-140)$ & $17.5(10-49)$ & $\mathrm{p}<0.05$ \\
Nematoda & $42(9-135)$ & $12.5(9-48)$ & $\mathrm{ns}$ \\
Copepoda & $2(0-6)$ & $2(0-6)$ & $\mathrm{p}<0.01$ \\
Ostracoda & $1(0-3)$ & 0 & $\mathrm{~ns}$ \\
Oligochaeta & $3(0-5)$ & $1(0-4)$ & \\
& & & \\
\hline
\end{tabular}

A total of 36 platyhelminth species was found at this site and the species distribution was similar in burrows and adjacent sediment. In May, abundances of grazing platyhelminths were significantly higher in adjacent sediment (Table 2). The sediment horizon from 5 to $10 \mathrm{~cm}$ depth, which was sampled additionally in May, contained only 1 to $6 \%$ of the meiofauna numbers of the entire sampling depth $(0$ to $10 \mathrm{~cm})$. Primarily nematodes occurred in the deeper sediment layers, and significantly more of these were found in the ambient sediment than in the burrows in this horizon (Table 2). Here, a gastrotrich, a gnathostomulid and platyhelminths of the genus Retronectes were also found

Other infauna examined (small macrofauna retained on the $125 \mu \mathrm{m}$ mesh) were more numerous in the burrows on the first sampling date (Table 2). Twelve polychaete species were distinguished at this site (listed by decreasing abundance: Armandia intermedia, Ancistrosyllis burrows of $S$. inflata did not differ from the ambient community when compared with multivariate analyses (ANOSIM: $\mathrm{R}=0.04, \mathrm{p}=0.307$ ).

Uca spp. Nematoda, accounting for about $90 \%$ of meiofauna at this site, were responsible for the difference in infaunal densities between burrows and adjacent sediment (Table 1). Other taxa were represented by only a few individuals. Ostracoda were only found in burrow samples (a total of 8 individuals). As in the case of Scopimera inflata, no community difference could be detected between burrows and ambient sediment with multivariate analyses (ANOSIM: $R=0.09, p=0.210$ ).

Lingula anatina. Here, the comparison was repeated before (November) and after (May) the wet season and yielded different results on each sampling occasion. Meiofaunal densities were higher in adjacent sediment on the first sampling date and higher in the burrows on the second (Table 2). In November, no separate meiofauna communities could be distinguished inside and outside of burrows, whereas in May separate communities were identified by clustering (Fig. 4b, d) and MDS ordination (not shown) (ANOSIM: $\mathrm{R}=0.72, \mathrm{p}=0.008$ ).
Table 2. Infaunal densities (individuals $5 \mathrm{~cm}^{-2}, 0-5 \mathrm{~cm}$; in May also $5-10 \mathrm{~cm}$; $\mathrm{n}=6$ each for 19 November 1988, $\mathrm{n}=5$ each for 4 May 1989; Hinchinbrook Channel) in burrows of Lingula anatina and sediment adjacent to the burrows. Values are medians with ranges; ns = not significant $(p>0.05)$

\begin{tabular}{|c|c|c|c|}
\hline & Burrows & $\begin{array}{l}\text { Adjacent } \\
\text { sediment }\end{array}$ & $\begin{array}{c}\text { Mann-Whitney } \\
U \text {-test }\end{array}$ \\
\hline \multicolumn{4}{|l|}{ November } \\
\hline \multicolumn{4}{|l|}{ Permanent meiofauna } \\
\hline Total & $384(263-680)$ & $538(372-650)$ & $p<0.05$ \\
\hline Nematoda & $350(190-630)$ & $480(280-555)$ & ns \\
\hline Copepoda & $15(4-45)$ & $25.5(17-46)$ & $p<0.05$ \\
\hline Platyhelminthes & $16.5(10-34)$ & $18.5(14-28)$ & ns \\
\hline Ostracoda & $4.5(0-9)$ & $8(0-11)$ & ns \\
\hline Kinorhynchia & $0(0-2)$ & $2(1-8)$ & $\mathrm{p}<0.01$ \\
\hline \multicolumn{4}{|l|}{ Temporary meiofauna } \\
\hline Total & $2(0-5)$ & $2(0-9)$ & ns \\
\hline \multicolumn{4}{|l|}{ Macrofauna } \\
\hline Total & $14(7-16)$ & $6(1-11)$ & $\mathrm{p}<0.01$ \\
\hline Oligochaeta & $2.5(0-6)$ & $0(0-2)$ & $p<0.05$ \\
\hline Polychaeta & $12(2-13)$ & $5(1-10)$ & $p<0.01$ \\
\hline Armandia intermedia & $6.5(2-11)$ & $0(0-1)$ & $p<0.001$ \\
\hline Crustacea & $0.5(0-1)$ & 0 & $p<0.05$ \\
\hline \multicolumn{4}{|l|}{ May } \\
\hline \multicolumn{4}{|l|}{ Permanent meiofauna } \\
\hline Total & $377(255-542)$ & $169(150-259)$ & $p<0.01$ \\
\hline Nematoda $0-5 \mathrm{~cm}$ & $350(240-450)$ & $150(120-230)$ & $p<0.01$ \\
\hline Nematoda $5-10 \mathrm{~cm}$ & $3(2-5)$ & $9.5(1-17)$ & $p<0.05$ \\
\hline Copepoda & $20(10-80)$ & $10(7-20)$ & $p<0.05$ \\
\hline Platyhelminthes & $6(3-9)$ & $9(6-15)$ & $p<0.05$ \\
\hline Grazers & $3(0-5)$ & $8(4-10)$ & $p<0.01$ \\
\hline \multicolumn{4}{|l|}{ Temporary meiofauna } \\
\hline Total & $1(0-4)$ & $0(0-1)$ & $\mathrm{p}<0.05$ \\
\hline \multicolumn{4}{|l|}{ Macrofauna } \\
\hline Total & $5(5-15)$ & $7(5-9)$ & ns \\
\hline Oligochaeta & $1(0-2)$ & $1(1-2)$ & ns \\
\hline Polychaeta & $4(2-12)$ & $4(3-7)$ & ns \\
\hline
\end{tabular}



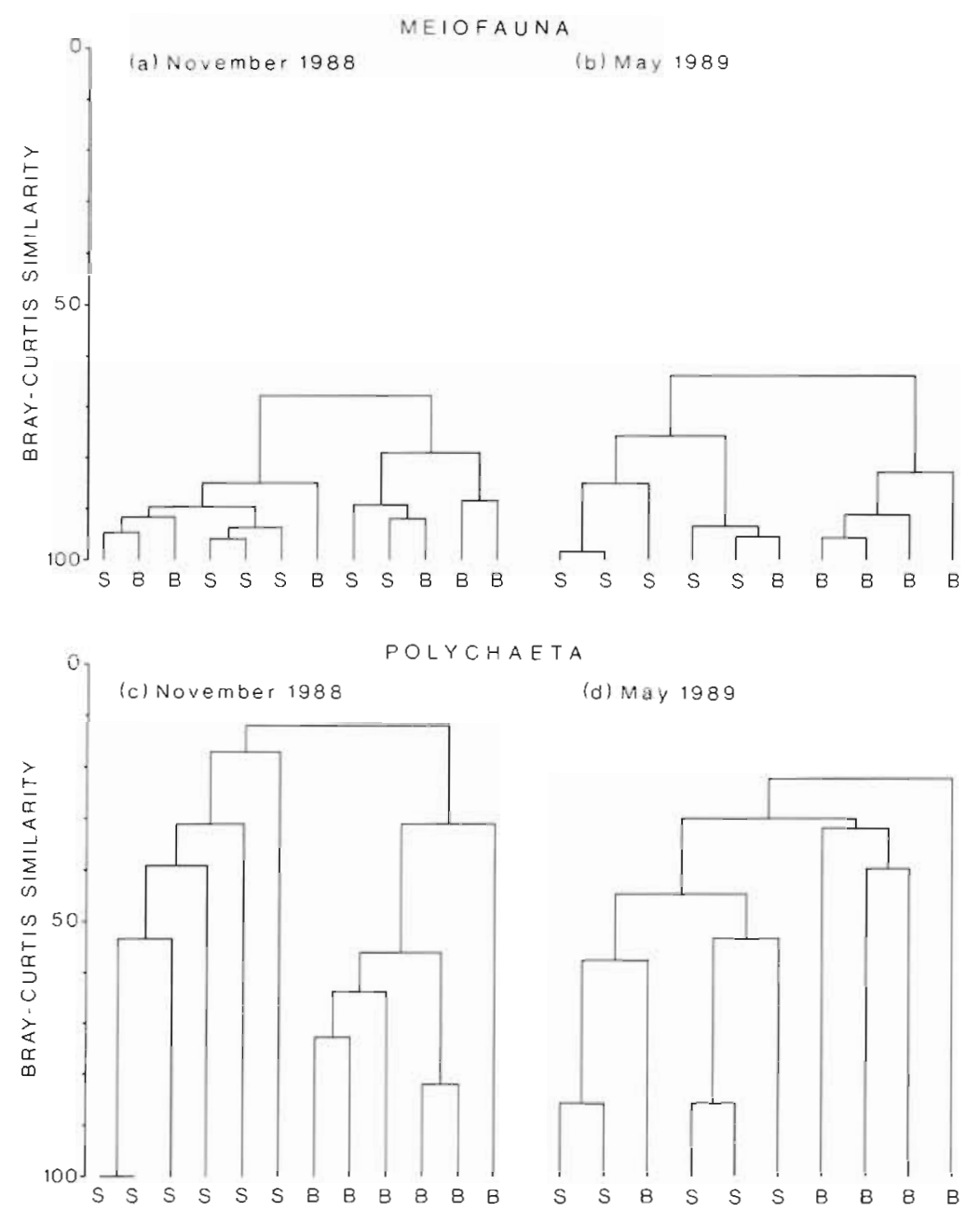

Fig. 4. Cluster analysis of community differences in burrows of Lingula anatina $(B)$ and adjacent sediment $(S)$ : $(a, b)$ for meiofauna (phylum level): (c, d) for polychaetes (species level)

community composition in the burrows differed from that in the adjacent sediment (Fig. 5) and this difference was significant (ANOSIM: $R=0.66, p=0.008$ ). On the species level, 15 platyhelminth species occurred in the burrows compared to 13 outside, with 9 species in common, which resulted in a low species similarity between the 2 sample sets (QS $=0.56$ ). The densities of 6 individual species (Myozona sp., Vannucia sp., Duplominona sp., Proseriata indet., Gyratrix sp., Carcharodorhynchus sp.) and of all predatory Platyhelminthes were significantly higher in the burrows (Table 3). However, the difference in the total platyhelminth community between burrows and ambient sediment was only slight (ANOSIM: $R=0.35, p=0.008$ ).

\section{Exclusion experiment}

The exclusion of callianassid shrimps was effective and the density was significantly reduced, down to 6 shrimps $\mathrm{m}^{-2}$ compared to 150 shrimps $\mathrm{m}^{-2}$ at the control sites $(p<0.001)$. No differences were detected in the density of Callianassa australiensis between control sites and ambient areas (165 shrimps $\mathrm{m}^{-2}$ ). The exclusion sites could still be distinguished after $1 \mathrm{yr}$, when on average 20 burrows $\mathrm{m}^{-2}$ were counted at the exclusion sites compared to 121 at the control sites $(\mathrm{p}<0.001)$. parva, Nereis sp., Sphaerosyllis sp., Exogone sp., Maldanidae indet., Capitella sp., Polydora sp., Syllidae indet., Schistomeringos sphairatolobus, Prionospio sp., Pygospio sp.) and in November this community was clearly different inside and outside of the Lingula anatina burrows (Fig. 4C) (ANOSIM: $\mathrm{R}=0.79, \mathrm{p}=0.002$ ). On the second sampling date, this was less pronounced (Fig. 4d) (ANOSIM: R = $0.35, \mathrm{p}=0.024$ ).

Callianassa australiensis. The burrows were inhabited by significantly more nematodes and platyhelminths, whereas temporary meiofauna (bivalve larvae) was more abundant outside of the burrows (Table 3 ). The infaunal
Table 3. Infaunal densities (individuals $5 \mathrm{~cm}^{-2}, 0-5 \mathrm{~cm}, \mathrm{n}=5$ each) in burrows of Callianassa australiensis and in sediment adjacent to the burrows. Haughton Estuary, 17 April 1989. Values are medians with ranges; ns = not significant $(p>0.05)$

\begin{tabular}{|lccc|}
\hline & Burrows & $\begin{array}{c}\text { Adjacent } \\
\text { sediment }\end{array}$ & $\begin{array}{c}\text { Mann-Whitney } \\
\text { U-test }\end{array}$ \\
\hline $\begin{array}{l}\text { Permanent meiofauna } \\
\text { Total }\end{array}$ & $305(180-362)$ & $131(82-200)$ & $\mathrm{p}<0.01$ \\
Nematoda & $190(130-230)$ & $100(60-120)$ & $\mathrm{p}<0.01$ \\
Copepoda & $44(16-86)$ & $25(7-50)$ & $\mathrm{ns}$ \\
Platyhelminthes & $25(19-46)$ & $12(7-16)$ & $\mathrm{p}<0.01$ \\
$\quad$ Predators & $20(15-28)$ & $10(1-14)$ & $\mathrm{p}<0.01$ \\
$\quad$ Grazers & $5(2-18)$ & $3(2-6)$ & $\mathrm{ns}$ \\
Ostracoda & $6(2-12)$ & $12(1-14)$ & $\mathrm{ns}$ \\
Temporary meiofauna & $5(2-12)$ & $7(5-14)$ & $\mathrm{p}<0.05$ \\
Total & $1(0-2)$ & $1(0-4)$ & $\mathrm{ns}$ \\
Polychaete larvae & $4(1-8)$ & $6(5-10)$ & $\mathrm{p}<0.05$ \\
Bivalve larvae & & & \\
\hline
\end{tabular}




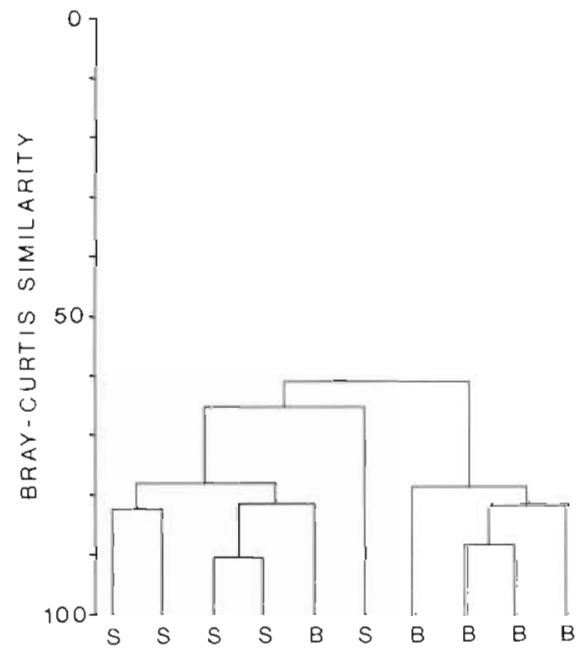

Fig. 5. Cluster analysis of infaunal community differences (phylum level) between burrows of Callianassa australiensis (B) and adjacent sediment (S)

Occasionally, tubes of a terebellid polychaete (Loima $\mathrm{sp}$. , fecal pellets of Heteromastus sp. and tracks of echiurids, snails, mudskippers and fiddler crabs were seen at the exclusion sites, just as in the ambient areas and at the control sites. This revealed that the implanted fly screen excluded only the callianassid shrimps, while none of the other tube- or burrow-building macrobenthic species was affected by the experimental treatment. The sampling at Week 11 coincided with activity of soldier crabs Mictyris longicarpus in the area and their feeding tracks covered the entire study area.

The absence of shrimp burrows had a strong effect on the meiofauna, whereas macrofauna, which occurred in low individual numbers, displayed only moderate responses. Significant reductions in abundances of infauna were apparent from the very beginning (Tables 4 \& 5), yet distinct communities could be identified by multivariate analyses only after several months of exclusion (Fig. 6). On the sampling date after $11 \mathrm{wk}$, infaunal numbers were lower than on previous dates and the exclusion and control sites could not be distinguished (Table 4).

For the meiofauna, nematode and copepod densities were significantly lower at the exclusion sites. Differences in densities of Platyhelminthes and Ostracoda were less pronounced. No consistent species-specific responses were detected among the Platyhelminthes, but grouped by feeding mode, grazing taxa were significantly more abundant at the control sites at Weeks $6(\mathrm{p}<0.05), 18(\mathrm{p}<0.01)$ and $53(\mathrm{p}<$ 0.05 ). The vertical distribution showed that meiofaunal densities in the exclusion treatments were reduced over the sediment depth sampled (Table 6). Eighty-three percent of the Platyhelminthes occurred in $0-1 \mathrm{~cm}$ sediment depth and only a few copepod specimens were found in the deeper sediment layer. After 18 and $53 \mathrm{wk}$, the meiofaunal communities of the exclusion and control sites were distinctly different (Fig. 6b, c) (ANOSIM: Week 18: $\mathrm{R}=0.79, \mathrm{p}=0.002$; Week 53: $\mathrm{R}=$ $0.43, p=0.004)$.

The macrofauna showed significantly reduced densities in the exclusions only after $1 \mathrm{wk}$ and after $1 \mathrm{yr}$, in both cases due to amphipods (Table 5). After 1 yr, bivalve recruitment was detected at the exclusion sites. The 12 polychaete species recorded in this area during the study occurred in low numbers and their distribution patterns did not react to the shrimp exclusions. However, the species similarity between exclusion and control sites decreased from $\mathrm{QS}=0.91$ after

Table 4. Meiofaunal densities (induviduals $3.69 \mathrm{~cm}^{-2}, 0-5 \mathrm{~cm}$ depth) in experimental exclusions of Callianassa australiensis and in treatment controls; $\mathrm{n}=7$ each for Weeks 1 to 11 and $n=6$ for Weeks 18 and 53. Values are medians with ranges; $n s=$ not significant $(p>0.05)$

\begin{tabular}{|lcccc|}
\hline & Week & Exclusion & Control & $\begin{array}{c}\text { Mann-Whitney } \\
\text { U-test }\end{array}$ \\
\hline Total meiofauna & 1 & $100(55-148)$ & $133(90-191)$ & $\mathrm{p}<0.01$ \\
& 6 & $95(43-119)$ & $160(54-206)$ & $\mathrm{p}<0.05$ \\
& 11 & $84(71-107)$ & $91(76-139)$ & $\mathrm{ns}$ \\
& 18 & $49(38-60)$ & $104.5(67-160)$ & $\mathrm{p}<0.001$ \\
& 53 & $76.5(50-135)$ & $134.5(89-151)$ & $\mathrm{p}<0.01$ \\
Nematoda & 1 & $66(36-123)$ & $97(64-124)$ & $\mathrm{p}<0.05$ \\
& 6 & $75(21-95)$ & $135(30-165)$ & $\mathrm{p}<0.05$ \\
& 11 & $60(43-87)$ & $69(45-118)$ & $\mathrm{ns}$ \\
& 18 & $29(24-40)$ & $68(48-113)$ & $\mathrm{p}<0.001$ \\
& 53 & $19.5(15-42)$ & $60(35-90)$ & $\mathrm{p}<0.01$ \\
& 1 & $7(0-39)$ & $29(9-43)$ & $\mathrm{p}<0.01$ \\
& 6 & $4(0-8)$ & $7(4-39)$ & $\mathrm{p}<0.05$ \\
& 11 & $3(0-5)$ & $4(0-7)$ & $\mathrm{ns}$ \\
& 18 & $8(2-11)$ & $13.5(0-24)$ & $\mathrm{p}<0.05$ \\
& 53 & $35(20-105)$ & $47(1-95)$ & $\mathrm{ns}$ \\
& & $14(9-24)$ & $20(10-23)$ & $\mathrm{ns}$ \\
& 1 & $16(10-24)$ & $17(10-24)$ & $\mathrm{ns}$ \\
& 6 & $20(10-28)$ & $20(8-36)$ & $\mathrm{ns}$ \\
& 11 & $9.5(8-15)$ & $14.5(12-19)$ & $\mathrm{p}<0.01$ \\
& 18 & $15(9-20)$ & $17(7-32)$ & $\mathrm{ns}$ \\
& 53 & $3(0-5)$ & $3(2-6)$ & $\mathrm{ns}$ \\
& 1 & $2(0-4)$ & $3(1-13)$ & $\mathrm{p}<0.05$ \\
& 6 & $1(0-7)$ & $2(0-5)$ & $\mathrm{ns}$ \\
& 11 & $1(0-2)$ & $2.5(0-5)$ & $\mathrm{p}<0.05$ \\
& 18 & $0(0-1)$ & $0(0-1)$ & $\mathrm{ns}$ \\
& 53 & & &
\end{tabular}


Table 5. Macrofaunal densities (individuals $15 \mathrm{~cm}^{-2}, 0-5 \mathrm{~cm}$ depth) in experimental exclusions of Callianassa australiensis and in treatment controls; $n=7$ for Weeks 1 to 11 and $n=6$ for Weeks 18 and 53. Values are medians w.th ranges; $\mathrm{ns}=$ not significant $(\mathrm{p}>0.05)$

\begin{tabular}{|c|c|c|c|c|}
\hline & Week & Exclusion & Control & $\begin{array}{c}\text { Mann-Whitney } \\
\text { U-test }\end{array}$ \\
\hline \multirow[t]{5}{*}{ Total macrofauna } & 1 & $4(1-10)$ & $19(0-35)$ & $\mathrm{p}<0.05$ \\
\hline & 6 & $3(1-62)$ & $7(1-60)$ & ns \\
\hline & 11 & $2(1-9)$ & $4(0-12)$ & ns \\
\hline & 18 & $3(0-12)$ & $1.5(0-5)$ & ns \\
\hline & 53 & $7(3-29)$ & $11.5(7-33)$ & $p<0.05$ \\
\hline \multirow[t]{5}{*}{ Polychaeta } & 1 & $1(0-2)$ & $2(0-4)$ & ns \\
\hline & 6 & $1(0-2)$ & $1(0-7)$ & ns \\
\hline & 11 & $1(0-2)$ & $0(0-2)$ & $p<0.05$ \\
\hline & 18 & $1.3(0-12)$ & $0.5(0-2)$ & ns \\
\hline & 53 & 0 & $0.5(0-1)$ & $p<0.05$ \\
\hline \multirow[t]{5}{*}{ Amphipoda } & 1 & $2(0-8)$ & $16(0-35)$ & $p<0.05$ \\
\hline & 6 & $1(0-61)$ & $1(0-59)$ & ns \\
\hline & 11 & $0(0-3)$ & $0(0-3)$ & ns \\
\hline & 18 & $0(0-1)$ & 0 & $p<0.05$ \\
\hline & 53 & $6(2-26)$ & $10(6-30)$ & $p<0.05$ \\
\hline \multirow[t]{5}{*}{ Bivalvia } & 1 & $0(0-1)$ & 0 & ns \\
\hline & 6 & $0\left(\begin{array}{ll}0 & 2\end{array}\right)$ & $0(0-1)$ & ns \\
\hline & 11 & $0(0-2)$ & $0(0-1)$ & ns \\
\hline & 18 & $0(0-1)$ & $0.5(0-1)$ & ns \\
\hline & 53 & $1.5(0-10)$ & $0.5(0-1)$ & $p<0.05$ \\
\hline \multirow[t]{5}{*}{ Oligochaeta } & 1 & $0(0-5)$ & $0(0-3)$ & ns \\
\hline & 6 & $0(0-1)$ & $0(0-4)$ & $p<0.05$ \\
\hline & 11 & $0(0-4)$ & $1(0-7)$ & $p<0.05$ \\
\hline & 18 & 0 & 0 & \\
\hline & 53 & 0 & $0(0-2)$ & $p<0.05$ \\
\hline
\end{tabular}

$1 \mathrm{wk}$ to 0.33 after $6 \mathrm{wk}$ and 0.57 after $18 \mathrm{wk}$. The presence or absence of shrimp burrows had no effect on the macrofaunal community composition and the null hypothesis (no differences between treatments) could not be rejected by ANOSIM.

\section{DISCUSSION}

The investigated macrobenthic burrows influenced the species distribution and abundance patterns of infauna in the studied tropical tidal flats and had a promotive effect on the benthos communities. Densities in burrows exceeded ambient densities 1.5 to 2.5 times. At sites where Callianassa australiensis was experimentally excluded, infaunal numbers were reduced to about $55 \%$ of control values. Nematodes were the taxon responding most to the presence/absence of burrows.

The effects of burrows on infauna varied with the type of burrow (Fig. 3). Burrows of Scopimera inflata and of fiddler crabs did not host a distinctive infaunal association. Burrows of Lingula anatina and Callianassa australiensis had a distinctive infaunal community, yet this pattern was not constant over time. In all cases, the burrows would have been a favourable habitat, as they offered a cooler environment than the sediment surface, where temperatures were usually about $28^{\circ} \mathrm{C}$ and could exceed $35^{\circ} \mathrm{C}$ (author's pers. obs.). The burrows provided refuge from desiccation and may thus be a less harsh environment during the summer months. This could explain some of the reported variations in abundance patterns. It is not yet known whether burrows also offer shelter from salinity changes following seasonal floods or monsoonal rains.
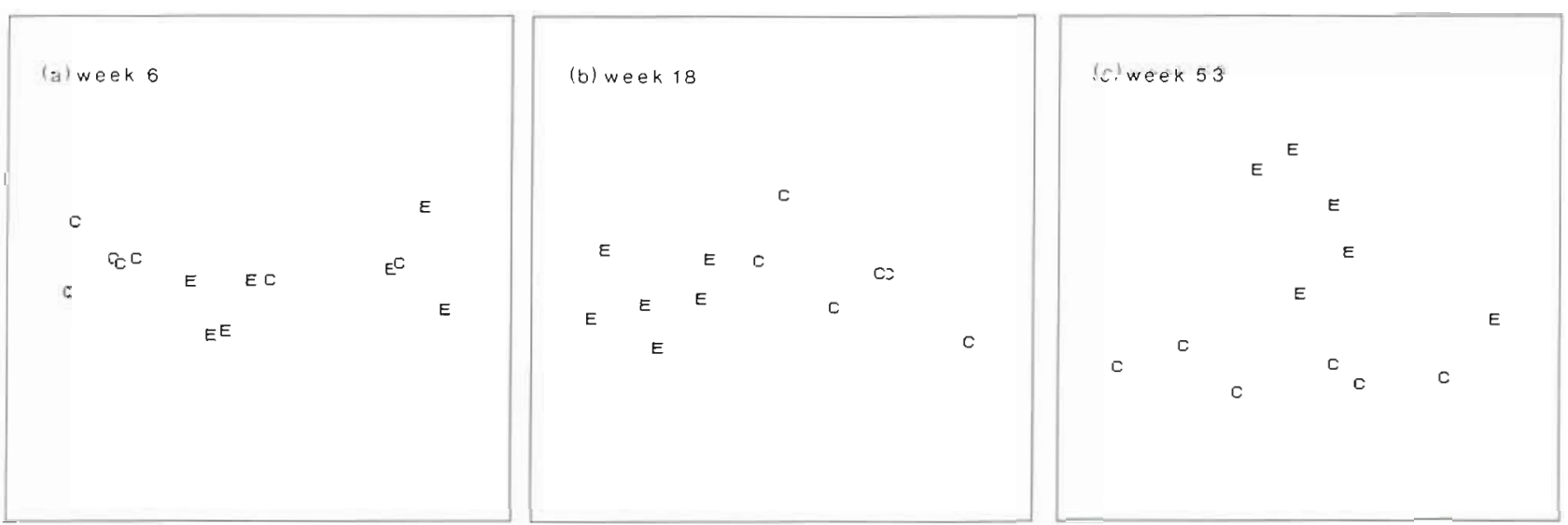

Fig. 6. MDS of the meiobenthic community (phylum level) in the course of the experiment. E: experimental exclusion of Callianassa australiensis; C: control sites. Stress values are: (a) 0.02, (b) 0.02, (c) 0.06 
Table 6. Depth distribution of meiofaunal densities (individuals $3.69 \mathrm{~cm}^{-2}, \mathrm{n}=7$ ) in experimental exclusions of Callianassa australiensis and treatment controls. Values are medians with ranges; ns $=$ not significant $(p>0.05)$

\begin{tabular}{|lcccc|}
\hline & $\begin{array}{c}\text { Depth } \\
(\mathrm{cm})\end{array}$ & Exclusion & Control & $\begin{array}{c}\text { Mann-Whitney } \\
\text { U-test }\end{array}$ \\
\hline Week 1 & & & & \\
Total meiofauna & $0-1$ & $83(47-130)$ & $104(57-172)$ & $\mathrm{p}<0.05$ \\
& $1-5$ & $17(8-32)$ & $29(19-36)$ & $\mathrm{p}<0.01$ \\
Nematoda & $0-1$ & $52(31-109)$ & $75(37-110)$ & $\mathrm{ns}$ \\
& $1-5$ & $14(5-24)$ & $23(14-27)$ & $\mathrm{p}<0.01$ \\
Week 6 & & & & $\mathrm{p}<0.05$ \\
Total meiofauna & $0-1$ & $72(32-97)$ & $133(45-164)$ & $\mathrm{p}<0.05$ \\
& $1-5$ & $17(6-27)$ & $27(9-61)$ & $\mathrm{p}<0.05$ \\
Nematoda & $0-1$ & $53(18-75)$ & $110(25-120)$ & $\mathrm{p}<0.05$ \\
& $1-5$ & $17(3-25)$ & $23(5-55)$ & $\mathrm{ns}$ \\
Week 11 & & & & $\mathrm{ns}$ \\
Total meiofauna & $0-1$ & $57(43-68)$ & $62(35-79)$ & $\mathrm{ns}$ \\
& $1-5$ & $36(18-50)$ & $45(17-60)$ & $\mathrm{ns}$ \\
Nematoda & $0-1$ & $33(27-40)$ & $33(29-60)$ & $30(24-58)$ \\
& $1-5$ & $25(18-37)$ & & \\
\end{tabular}

munity distinct from that in the adjacent sediment. Yet, the significantly increased density of nematodes in burrows of fiddler crabs recorded here is in accordance with studies on fiddler crab burrows from other parts of the world. Bell et al. (1978) reported increased meiofaunal abundances in fiddler crab burrows in a salt marsh and they attributed the increase to a more favourable food supply, following microbial decay of fecal pellets. Similarly, DePatra \& Levin (1989) found higher infaunal densities in fiddler crab burrows, but in addition to an increased food supply in the burrows, they discovered that meiofauna were passively deposited in natural and artificial burrows. I observed fiddler crabs plugging their burrows with a sediment disc before the incoming

Posey (1986) found seasonal differences in the effect of Callianassa californiensis on amphipods. Thus, caution must be exercised when drawing inferences derived from single samplings.

The differences in infauna accommodated in burrows may be related to specific attributes of the respective burrow type and to possible interactions between host and co-residents. This is discussed below for each burrow type studied.

\section{Burrows of ocypodid crabs}

Burrows of Scopimera inflata have a depth of about $30 \mathrm{~cm}$, so that the crabs can reach the water level at low tide (McCulloch \& McNeill 1923-26). The burrows of fiddler crabs also reach the water level. In salt marshes, the burrowing activity of fiddler crabs can increase the surface area by $59 \%$ (Katz 1980). At my study site, several species of fiddler crabs coexisted and could not be distinguished by the burrow opening. Ocypodid crabs excavate their burrows anew at every low tide (Altevogt 1957, Fielder 1970). The crabs use the burrows as refuges during high tide and as occasional retreats during their activities on the surface at low tide (Reise 1985). Sand is cleared out of the burrow and deposited as pellets on the surface before other activities commence. As the water table falls during low tide, $S$. inflata continually deepens the burrow (Fielder 1970). This process of excavation makes the burrows of Scopimera and Uca an unstable habitat for associated fauna. The turnover of sediment due to crab activity may explain why the higher densities of some meiofaunal taxa in the burrows did not result in a com- tide arrived. Thus it is unclear whether passive deposition can explain the increased infaunal densities in the Uca burrows encountered here. Positive effects of fiddler crab burrows are in contrast to the possible negative effect of Uca predation on meiofauna (Hoffmann et al. 1984). Dye \& Lasiak (1986) yielded a 2- to 5-fold increase of meiafauna numbers in fiddler crab exclusion experiments set up on a tropical mud bank, but they argued that microheterotrophs, not meiofauna, were the major food source of the crabs.

\section{Burrows of Lingula anatina}

Compared to ocypodid crabs, the brachiopod Lingula anatina is more sessile. On the sediment surface, its burrow openings are distinguishable as slot-like gaps. Lingulid brachiopods dig burrows with their valves (Thayer \& Steele-Petrovíc 1975, Morton \& Morton 1983). Once established, the burrows are maintained by vertical movements. Thus, disturbances along the burrow linings are less pronounced than in the case of ocypodids and the burrows are a more persistent habitat for infauna. The higher densities and community differences of infauna recorded in the $L$. anatina burrows were not consistent over time and at present it remains unknown whether this reflects seasonal variation. The burrows may be optional sites for infauna, but more has to be known about speciesspecific responses before a conclusion can be drawn. The polychaete Armandia intermedia, which was more abundant in the burrows, has been recorded throughout the studied tidal flats (Dittmann unpubl.) and the burrows are not an obligatory habitat for this taxon 
The finding of a Gnathostomulida and a Retronectes in the lower horizon of the adjacent sediment is in contrast to the recorded association of these taxa with tail shafts of Arenicola marina (Reise 1981, 1987).

\section{Burrows of Callianassa australiensis}

The burrows of Callianassa australiensis are extensive and reach over $1 \mathrm{~m}$ in depth (Kenway 1981). Sampling of the lower realms of the burrows was methodologically impossible and throughout this study only the top parts of the burrows were considered. Callianassid shrimps are mobile within their roomy burrow system, and all their activities take place below ground. Meiofaunal densities were significantly higher in the burrows of $C$. australiensis and the absence of burrows led to a significant reduction in meiofaunal densities at the exclusion sites and to different meiofaunal communities between the exclusion and control sites. In the vertical dimension, meiofauna was more numerous in the lower horizon of control sites than exclusions. The effect on the meiofauna became more and more pronounced in the course of the experiment.

The reduced abundance I recorded in the shrimp exclusions is comparable to the effect of lugworm exclusions in an experiment conducted by Reise (1983), from which he derived the importance of promotive effects in tidal flat communities. But the results of this study are in contrast to accounts of reduced meiobenthic and especially nematode densities in burrows of Callianassa trilobata from an intertidal sandflat in Florida, USA (Dobbs \& Guckert 1988), and in burrows of Callianassa sp. in a subtidal reef lagoon (Alongi 1986). In an experimental study, Branch \& Pringle (1987) recorded reduced meiofaunal numbers with increasing densities of Callianassa kraussi, but Dye \& Furstenberg (1978) found a positive relationship between the depth distribution of meiofauna and this shrimp species

What could attract meiofauna to or repel them from shrimp burrows? The extension of oxygenated sediment surface to greater depths corresponds to an extension of habitat. Food supply for meiofauna is enhanced, as chlorophyll a values are higher in burrow linings (Dobbs \& Guckert 1988), and in the presence of Callianassa kraussi more chlorophyll was found in deeper sediment layers than on the surface (Branch \& Pringle 1987). These authors also recorded higher bacteria numbers along the burrow linings, and along with Frankenberg et al. (1967) they pointed out the trophic significance of Callianassa fecal pellets. Altogether, this is a classical scenario for sediment amelioration sensu Reise (1985). Although chlorophyll and bacteria were not analysed in my study, irrigation and fertilization of C. australiensis must be considered as possible factors enhancing meiofauna in the burrows. In the experiment, densities of grazing Platyhelminthes were always higher at the control sites, which suggests an increased availability of benthic diatoms in the presence of shrimps. This promotive effect might not have occurred in the other cases cited above, as the level of bioturbation attributable to Callianassa may vary with species (Griffis \& Suchanek 1991). However, the methods available for calculating sediment turnover in Callianassidae vary widely, and comparisons of this parameter are at present impossible (Rowden \& Jones 1993).

The sampling after 11 wk coincided with activity of soldier crabs Mictyris longicarpus. These crabs emerge at irregular intervals and pelietize the entire sediment surface during their feeding treks, reducing meiofaunal numbers by predation (Dittmann 1993). The depth distribution (Table 6) showed that at all experimental sites, meiofaunal numbers were reduced in the surface sediment layer, whereas densities in the 1-5 cm horizon were still comparable to previous values. This hints at a hierarchy of effects by macrofauna on smaller infauna. An experiment to study the effects of various combinations of presence/absence of shrimp and soldier crabs unfortunately failed following unfavourable weather conditions.

Numbers of temporary meiofauna, however, were reduced in the burrows of Callianassa australiensis and juvenile bivalves were almost exclusively recorded in sediment adjacent to burrows and in exclusion sites. When digging up sediment, shells of dead bivalves $<5 \mathrm{~mm}$ in size were often found at depths of about $20 \mathrm{~cm}$. Peterson (1977) described a competitive interaction for C. californiensis and the bivalve Sanguinolaria nuttallii, in which he considered direct consumption and burial of newly recruited mussels to be the mechanism of interaction. After $3 \mathrm{yr}$, the bivalves were well established at his shrimp exclusion site (Peterson 1984). In a similar way, $C$. australiensis can inhibit the recruitment of bivalves on the tidal flats of North Queensland.

Gammarid amphipods, which have already been described by Kenway (1981) as commensals in the burrows of Callianassa australiensis, were absent from my exclusion sites and thus seem to be obligate burrow inhabitants.

This investigation showed that burrows of macrobenthic organisms in the tropics have promotive effects similar to those reported from other regions. In some cases, the interactions are complex and the burrow host can exert contradictory effects on associated fauna. More studies are needed to elucidate the deeper realms of the thalassinidean burrows that still remain cryptic. 
Note added in proof: Callianassa australiensis has recently been renamed Trypaea australiensis.

Acknowledgements. This investigation was funded by a postdoctoral fellowship of the Deutsche Forschungsgemeinschaft (DFG grant III 02-Di 396/1-2). The Australian Institute of Marine Science provided excellent research facilities and special thanks to go the mangrove team, marine operations and the crew of the research vessel 'Harry Messel' A big thanks goes to J. van Kampen and A. Taplin, who could not resist getting muddy and helped to set up the experiment. The help of numerous volunteers who joined my field trips over the years is very much appreciated. I am grateful to I. Kroncke for providing access to the PRIMER software package and I thank her and $\mathrm{K}$. Fabricius for discussions on the manuscript. Comments by anonymous reviewers helped to improve the manuscript.

\section{LITERATURE CITED}

Aller RC, Yingst JY, Ulman WJ (1983) Comparative biogeochemistry of water in intertidal Onuphis (Polychaeta) and Upogebia (Crustacea) burrows: temporal patterns and causes. J Mar Res 41:571-604

Alongi DM (1986) Population structure and trophic composition of the free-living nematodes inhabiting carbonate sands of Davies Reef, Great Barrier Reef, Australia. Austr J Mar Freshwat Res 37:609-619

Alongi DM (1987) Intertidal zonation and seasonality of meiobenthos in tropical mangrove estuaries. Mar Biol 95: $447-458$

Alongi DM (1990) The ecology of tropical soft-bottom benthic ecosystems. Oceanogr Mar Biol A Rev 28:381-496

Altevogt R (1957) Beiträge zur Biologie und Ethologie von Dotilla blanfordi Alcock und Dotilla myctiroides (MilneEdwards) (Crustacea Decapoda). Z Morphol Ökol Tiere 46:369-388

Bell SS (1985) Habitat complexity of polychaete tube-caps: influence of architecture on dynamics of a meioepibenthic assemblage. J Mar Res 43:647-671

Bell SS, Watzin MC, Coull BC (1978) Biogenic structure and its effects on the spatial heterogeneity of meiofauna in a salt marsh. J Exp Mar Biol Ecol 35:99-107

Bell SS, Woodin S (1984) Community unity: experimental evidence for meiofauna and macrofauna. J Mar Res 42: $605-632$

Branch GM, Pringle A (1987) The impact of the sand prawn Callianassa kraussi Stebbing on sediment turnover and on bacteria, meiofauna, and benthic microflora. J Exp Mar Biol Ecol 107:219-235

Brenchley GA (1981) Disturbance and community structure: an experimental study of bioturbation in marine softbottom communities. J Mar Res 39:767-790

Clarke KR (1993) Non-parametric multivariate analyses of changes in community structure. Aust J Ecol 18:117-143

DePatra KD, Levin LA (1989) Evidence of the passive deposition of meiofauna into fiddler crab burrows. J Exp Mar Biol Ecol 125:173-192

Dittmann S (1990) Mussel beds-amensalism or amelioration for intertidal fauna? Helgoländer Meeresunters 44: $335-352$

Dittmann S (1993) Impact of foraging soldiercrabs (Decapoda: Mictyridae) on meiofauna in a tropical tidal flat. Rev Biol Trop 41(3): 627-637

Dittmann S (1995) Benthos structure on tropical tidal flats of Australia. Helgoländer Meeresunters 49:539-551
Dobbs FC, Guckert JB (1988) Callianassa trilobata (Crustacea: Thalassinidea) influences abundance of melofauna and biomass, composition, and physiologic state of microbial communities within its burrow. Mar Ecol Prog Ser 45: $69-79$

Dye AH, Furstenberg JP (1978) An ecophysiological study of the meiofauna of the Swartkops Estuary. 2. The meiofauna: composition, distribution, seasonal fluctuation and biomass. Zoologica Africana 13(1):19-32

Dye AH, Lasiak TA (1986) Microbenthos, meiobenthos and fiddler crabs: trophic interactions in a tropical mangrove sediment. Mar Ecol Prog Ser 32:259-264

Fielder DR (1970) The feeding behaviour of the sand crab Scopimera inflata (Decapoda, Ocypodidae). J Zool 160: $35-49$

Frankenberg D, Coles SL, Johannes RE (1967) The potential trophic significance of Callianassa major fecal pellets Limnol Oceanogr 12:113-120

Griffis RB, Suchanek TH (1991) A model of burrow architecture and trophic modes in thalassinidean shrimp (Decapoda: Thalassinidea). Mar Ecol Prog Ser 79:171-183

Hoffmann JA, Katz J, Bertness MD (1984) Fiddler crab deposit-feeding and meiofaunal abundance in salt marsh habitats. J Exp Mar Biol Ecol 82:161-174

Hurlbert SH (1984) Pseudoreplication and the design of ecological field experiments. Ecol Monogr 54:187-211

Katz LC (1980) Effects of burrowing by the fiddler crab, Uca pugnax (Smith). Estuar Coast Mar Sci 11:233-237

Kenchington RA, Hammond LS (1978) Population structure, growth and distribution of Lingula anatina (Brachiopoda) in Queensland. Aust J Zool 184:63-81

Kenway MJ (1981) Biological studies of Callianassa australiensis (Dana). Honours thesıs, James Cook University, Townsville

McCulloch AR, McNeill FA (1923-26) Notes on Australian Decapoda. Rec Aust Mus 14:49-59

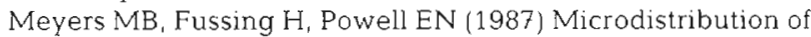
interstitial meiofauna, oxygen and sulfide gradients, and the tubes of macro-infauna. Mar Ecol Prog Ser 35:223-241

Moore HB (1972) Aspects of stress in the tropical marine environment. Adv Mar Biol 10:217-269

Morton B, Morton J (1983) The sea shore ecology of Hong Kong. Hong Kong University Press

Murphy RC (1985) Factors affecting the distribution of the introduced bivalve, Mercenaria mercenaria, in a California lagoon - the importance of bioturbation. J Mar Res 43:673-692

Peterson CH (1977) Competitive organization of the softbottom macrobenthic communities of southern Californian lagoons. Mar Biol 43:343-359

Peterson $\mathrm{CH}$ (1984) Does a rigorous criterion for environmental identity preclude the existence of multiple stable points? Am Nat 124(1):127-133

Posey $\mathrm{MH}$ (1986) Changes in a benthic community associated with dense beds of a burrowing deposit feeder, Callianassa californiensis. Mar Ecol Prog Ser 31:15-22

Posey MH (1987) Influence of relative mobilities on the composition of benthic communities. Mar Ecol Prog Ser 39:99-104

Posey MH, Dumbauld BR, Armstrong DA (1991) Effects of burrowing mud shrimp, Upogebia pugettensis (Dana), on abundances of Macro-infauna. J Exp Mar Biol Ecol 148: $283-294$

Reise K (1981) Gnathostomulida abundant alongside polychaete burrows. Mar Ecol Prog Ser 6:329-333

Reise K (1983) Experimental removal of lugworms from marine sand affects small zoobenthos. Mar Biol 74:327-332

Reise K (1985) Tidal flat ecology. Springer, Berlin 
Reise K (1987) Spatial niches and long-term performance in meiobenthic Plathelminthes of an intertidal lugworm flat. Mar Ecol Prog Ser 38:1-11

Reise K (1991) Macrotauna in mud and sand of tropical and temperate tidal flats. In: Elliott M, Ducrotoy JP (eds) Estuaries and coasts: spatial and temporal intercomparisons. Olsen \& Olsen, Fredensborg, p 211-216

Rhoads DC, Young DK (1970) The influence of depositfeeding organisms on sediment stability and community trophic structure. J Mar Res 28:150-178

Rowden AA, Jones MB (1993) Critical evaluation of sediment turnover estimates for Callianassidae (Decapoda: Thalassinidea). J Exp Mar Biol Ecol 1.73:265-272

Sanders HL (1968) Marine benthic diversity: a comparative study. Am Nat 102(925):243-282

Schaffner LC (1990) Small-scale organism distributions and patterns of species diversity: evidence for positive interactions in an estuarine benthic community. Mar Ecol Prog Ser 61:107-117

This article was submitted to the editor
Sørensen TA (1948) A method to establish groups of equal amplitude in plant sociology based on similarity of species content, and its application to analyses of the vegetation on Danish commons. Biol Skr 5:1-34

Suchanek TH (1983) Control of seagrass communities and sediment distribution by Callianassa (Crustacea, Thalassinidea) bioturbation. J Mar Res 4 1:281-298

Suchanek TH, Colin PL (1986) Rates and effects of bioturbation by invertebrates and fishes at Enewetak and Bikini atolls. Bull Mar Sci 38(1):25-34

Thayer CW, Steele-Petrovic HM (1975) Burrowing of the lingulid brachipod Glottidia pyramidata: its ecological and paleoecological significance. Lethaia 8:209-221

Woodin SA (1976) Adult-larval interactions in dense infaunal assemblages: pattern of abundance. J Mar Res 34: $25-41$

Woodin SA (1978) Refuges, disturbance, and community structure: a marine soft-bottom example. Ecology 59: $274-284$

Manuscript first received: August 25, 1995

Revised version accepted: December 1, 1995 